\title{
What journalism tells us about memory, mind and media
}

\author{
Barbie Zelizer \\ Annenberg School for Communication, University of Pennsylvania, Philadelphia, PA, USA \\ Corresponding author: Barbie Zelizer, email: bzelizer@asc.upenn.edu
}

\begin{abstract}
This article looks to journalism in order to understand the relationship between memory, mind and media more fully. Using the urgency that characterises the current news environment as a reflection of broader information flows, the article considers journalism's embrace of complex time to address the demands of speed. It suggests that the temporal practices adopted by both individual journalists and the journalistic community offer a model for institutions wrestling with the ontological uncertainty generated by current times, providing mechanisms to navigate and even offset the unending demands of simultaneity, immediacy and instantaneity.
\end{abstract}

Keywords: Journalism; news; memory; time; ontology; Goffman

\section{Article}

Memory, both individual and collective, is like an overcoat for different body types. Some memories sit snugly on the bodies that host them, while others orient towards a loose fit. But in each case, what we know about its trappings stretches and transforms, providing new coordinates and details that help us appraise how it works across contexts.

This article argues that journalism offers an overcoat for memory that may be relevant for far more body types than at first appears. The memory work that occurs in journalism has much to teach us about the relationship of memory to mind and media. Because journalism is primarily a temporal enterprise whose newswork is timebound for both individual journalists and the journalistic community writ large (Zelizer 2018), the ability to accommodate memory bears traits that are not always or readily shared by other environments spawning memory practices. Yet the calamitous events of the past two years - among them a global and as-yet uncontrolled pandemic, intensifying racial violence and misogyny, climate emergency and the spread of authoritarian governments everywhere - have created an ongoing urgent and rapacious need for immediate information on multiple fronts and varying scales. How do such competitive holds on journalism's resources affect its temporality and the ensuing mnemonic work that both individuals and the community undertake? And do they tell us anything about the temporal and mnemonic capacities of other institutional settings? At a point in which a cascade of events, problems and issues demands critical attention, journalism's approach to time may be offering a template that clarifies how memory might work across the board.

(c) The Author(s), 2021. Published by Cambridge University Press. This is an Open Access article, distributed under the terms of the Creative Commons Attribution licence (http://creativecommons.org/licenses/by/4.0/), which permits unrestricted re-use, distribution and reproduction, provided the original article is properly cited. 


\section{Temporality, memory and ontology}

The need to conceptualise the fuller extent of time's impact on memory has recently drawn the attention of scholars in memory studies. As Hristova et al $(2020,777)$ observe in their special issue of Memory Studies on the topic, the time concepts underlying both theoretical and empirical work on memory remain largely 'undiscussed and undefined', despite the fact that 'time, and how we conceptualize it, is a, if not the, foundational basis for creating and analyzing memory'. Collective memory, they argue, 'could be defined as the sociocultural process of producing time in society' (778). Accommodating the simultaneity of multiple temporalities - past, present and future, to say nothing of the various in-between states that combine them, such as the 'immediate past' or 'recent past' (Neiger and Tenenboim-Weinblatt 2016) - collective memory's very mandate is providing a sense of time.

Scholarly work on time and memory often begins with tweaking the dominance and simplicity of linear time. Examples abound: the time maps of Zerubavel (2005), palimpsests of Huyssen (2003) or futures past of Koselleck (2004). Yet, as Erll (2020, 861) notes, scholarly projects on temporality tend to look for epistemological devices, not ontological ones: memory studies continue to embrace a Newtonian concept of empty and linear time as its ontological basis, a regime that is 'not the only, and possibly not the most valid, model any longer, and ... is deeply implicated in modernity's capitalist, colonialist and racist orders'. Failing, then, to accommodate time's fuller texture in memory studies renders memory work and its conceptualisation fallible.

It is on this point that journalism may have something to offer the field of memory studies and the understanding of how memory impacts its relationship with the individuals and communities that use it. Unlike most other institutional settings, journalism's reliance on time is ontological, for without time, journalism does not exist. As the core knowledge formation within journalism, time constitutes an often unacknowledged but nonetheless central determinant of what counts in newsmaking - as boundary, perspective, standard and assessment. To draw from Adam's lament about scholarly approaches to time $(1990,15)$, it is understood as 'a sense, a measure, a category, a parameter, and an idea'. If time were to dissipate, so would journalism.

But the ontology of journalism is shaky, and that is no small matter. If ontology is, following Latour $(2017,47)$, the 'struggle to have the right to stand in one's own time and place', then questions everywhere about what journalism is, what it is for and who gets to say are direct reflections of journalism's precarious standing in the world. As Ryfe $(2019,206)$ reminds us:

The single biggest challenge facing Western journalism today, and especially American journalism, is not economic or political, it is ontological. The challenge arises from this fact: there has never been a time in which more news is produced than today, yet not since the 19th century has so little of it been produced by journalists.

Because time is such a central part of journalism's identity, journalism's relation to it becomes particularly instrumental for newswork to survive. And what is instrumental for newswork may have ramifications on the current temporal and mnemonic activity in other institutions with ontological concerns as well.

What does it mean to position temporality as part of journalism's ontological arsenal? We need first to distinguish between the rhetoric and reality that motivate journalistic action. Although the rhetoric of news claims to thrive on a fundamentally shrunken version of time that sandwiches the news between historical recording - to which journalism 
is expected to turn over its first draft of events - and the raw material of occurrences in real time, the situation on the ground is more complex. As journalists are forced to respond practically to immediate circumstances, such as weather or violence, and repair normatively to expectations of a continuous, truthful and clear record of the here-and-now, the granularity of journalistic temporality comes into view. The balance between practical and normative objectives - and between individual journalists and the shared community with which they identify - is exhausting to sustain, especially when journalism is tasked with covering the simultaneous emergence of multiple intense and often unresolvable circumstances. As Reich and Godler $(2014,608)$ noted, temporality is central to journalism, but it is also a 'finite and depletable resource always threatening to run out'.

\section{The complex time of journalism}

The terminable nature of journalistic temporality offers an opportunity for assessing how institutional environments might work with time when faced with overtaxed conditions. The threat of time's depletion makes necessary the kind of temporal activity that goes beyond a rhetorical embrace of the simplified and aspirational attributes thought to exist across variable conditions. The journalistic temporal record is more than just accounting for a presumably stable here-and-now. The threat of depletion calls for temporal activity that adheres not to a notion of empty or linear time, but one that generates complexity.

Complex time is useful in addressing journalism's ontological precarity. Goffman's (1959) notion of frontstage and backstage behaviour can be helpful in underscoring why this is so. Goffman argues that performative action, which surfaces in both journalists and the journalistic community, embraces two kinds of practices: those that are reserved for frontstages, where they are in full visibility of others, and those that unfold on backstages, where visibility is limited to a select few. A frontstage of action is necessary to signal to others that acknowledged norms and standards are in place, have been learned and are reliably and systematically being enacted via identifiable routines. By contrast, the backstage hosts activity that often unfolds with less inhibition and normativity, more creativity and freedom. Drawing from the knowledge that frontstages have communicated what needs to be stated and shared, backstages foster action that is thought to be more heartfelt, meaningful and genuine; backstages are also the place that promises adjustment, harbouring challenges, misjudgements and errors until they can be resolved. Complex time works across front and backstages, and it is the continuum connecting the two that renders it complex. It is also the material that helps form the mnemonic work associated with newsmaking.

\section{Journalism's frontstage}

Journalism's frontstage is determined first by its ongoing normative accommodation of ever-hastening delivery speeds. Time upholds journalism as an account of the present, distinguishing it from other record-keeping systems, and prompts journalists to embrace speed as instrumental for accomplishing work. Although the nod to speed is widely acknowledged as the default setting of modernity (Keightley 2012), it has special resonance for journalists, who easily adopt the practices and qualities fostering it: instantaneity, immediacy, proximity, liveness, novelty, nowness and firstness (Sheller 2015; Ananny 2018; Usher 2018; Zelizer 2021). Even activities that in the past were not associated with speed are now judged by how nimbly they can unfold. The Washington Post, for instance, published an obituary for Fidel Castro in 2016, which hid an extensive gap between the times it was written and disseminated. Following the adage that the obit 
that comes out first, or at least fast, can win the day', the obituary had been written by a man who had died ten years before the Cuban leader but had written his obituary two decades before that, adding to the "stockpiles of pre-written obits, known as "pre-writes" or "advancers," [that create] vast portfolios of deaths foretold' (Farhi 2021).

Sometimes the nod to speed characterising journalism's frontstage engenders errors of interpretation. Consider one of the biggest mishaps in United States coverage of the Trump administration: its mishandling of a reputed 35-page file called the Steele Dossier, which documented Trump's nefarious dealings with Russia as well as claims of a salacious 'pee tape'. First reported by Buzzfeed in 2017 and soon thereafter circulated across the media, in 2019 and 2021 it was declared fictitious and wrong by two US federal investigations. Compounding what the Columbia Journalism Review called 'a lot of nonsense and misdirection' in much of Trump's coverage (Pope 2021), speed was responsible for entrenching an erroneous record, and the normative frontstage that housed it lingered longer than it should have. Individual journalists protested the error from the beginning: The Washington Post reporter Erik Wemple, for instance, pressured repeatedly for media accountability in a 14-part series, pronouncing that the more we learn about the Steele Dossier, the more we need media organizations to look back, critically, on their coverage' (Wemple 2020). By late 2021, the Post had corrected and retracted portions of articles that relied on the dossier. But retractions and admissions of the error by those who committed it most explicitly have been uneven, a circumstance that allows it, at least partly, to remain in mnemonic oblivion.

Journalism's frontstage exists primarily for those outside of journalism. It reminds them of journalism's normative role in registering important items on the public agenda. Press conferences, for instance, are filled with ritual conventions that are performed in familiar and proven ways, but journalists attend not necessarily because they expect to secure new information but because their bodily presence is part of how they accrue authority. Their questions follow occupational scripts that uphold that aim, accomodating mnemonic cues about which questions to ask and how. This frontstage activity foregrounds normative and standardised action that helps those beyond journalism recognise journalists as part of a community tasked with providing the news.

The frontstage of newsmaking signals to other institutional settings how the journalistic community and its journalists are thought to respond to time - quickly, energetically and wholeheartedly - and positions their activity as a prototype for that of other environments: medical establishments, transportation frameworks, policing and security systems, educational enterprises, the market and politics. While this entrenches the news as a first alert, it does not mean that institutions lack their own way of connecting to time. But the pacing that ensues from the rhetorical insistence on speed in newsmaking offers a model for how information might need to be processed across the board in times of emergency, crisis or uncertainty.

Journalism's frontstage, however, and its normative pivot to speed, does not exhaust all of its temporality. Its backstage generates a less normative but more intricate and realistic picture of what its temporal practices look like.

\section{Journalism's backstage}

Journalism's backstage involves practices and qualities that go beyond the normative assignation of the news to the present and demonstrate the internal variability of journalistic time. Backstages offer a trove of granular temporal activity, much of which contradicts itself, resolves errors and misjudgements and gives journalists a way to revisit earlier action. As an internal corrective to what appears to be journalism's temporal simplicity, backstages show how complex journalistic temporality actually is. 
To begin, much of journalism's backstage work is itself an act of memory. Routines, classifications and typifications that guide journalists in what to do are also reminders of what they have done in the past (Olick 2014). News judgement offers a useful example: it accounts for why Queen Elizabeth's illness might secure coverage while the illnesses of countless others are passed over, or why the beginnings and ends of wars might be covered while their middles go unremarked. Journalists learn to recognise cues that situate their judgement calls as newsworthy or not. In some cases, journalists invoke experiences of the past so as to accomplish work in the present: securing coverage by being on time or at the right location, turning to sources with a proven track record, corroborating sources, accommodating routines that have already fostered unencumbered newsmaking. In other cases, they nod to the future in what Tenenboim-Weinblatt (2013b) calls 'prospective collective memory': anticipating events, predicting or pitching stories, organising around future deadlines, projecting developments and seeking feedback, archiving. All of these tasks depend on memory, both individual and collective, and none would seem obvious or appealing without precedent.

Second, time shapes the narrative core of journalistic craft and harnesses its power via familiarity and memorability. News narrative involves formulaic storytelling, which delivers time-proven relays that accommodate mnemonic tools by dipping into the past for clarity, consonance and coherence. Journalists regularly use tools like analogy, comparison, redress to earlier events or an invite to nostalgia, thought to enhance a news story's understanding. Thus, the end of the war in Afghanistan is compared to Vietnam for its futility and to the fall of Baghdad for its erroneous understanding (Bailey 2021). Because memory undergirds news stories through acts of delineation (eras), evaluation and measurement (yardsticks), comparison (analogies) and elucidation (lessons) (Lang and Lang 1989), the past becomes embedded in the very formulas by which the news is crafted. The reportage of natural disasters is hard to imagine without the formulas that strap them in place: widespread accounts of destruction and loss of human life are almost invariably matched with personal stories of heroism and survival. Too much of one or the other does not ring true, even though truth has less to do with one's appraisal than familiarity and fidelity to prior expectations.

Third, many aspects of the news record accommodate time explicitly and would not exist without it. These range from the obvious - obituaries, anniversary journalism, retrospectives and commemorative journalism - to the more suggestive, when journalists rely on historical contexts and historical analogies in shaping their coverage (Edy 1999). Thus, multiple journalists are framing current tensions between the USA and China as a new Cold War (Edel and Shullman 2021). The point here is that journalists try to render contemporary news comprehensible by situating it against the past. Much of Time Inc's 'Person of the Year', People's 'Sexiest Person of the Year' and other widespread end-of-year lists are also mnemonic conventions, involving the review of persons or events over a predetermined time period, comparison of them to each other and adjudication of which emerges as triumphant. Though all of this leaves open the question of which past should and can be brought to bear, the nod in its direction is a conventional act of journalistic explanation and clarification.

Although this backstage of journalistic temporality is not an obvious aspect of the normative picture that journalism tends to project of itself and its dealings with time, multiple scholars have established that journalistic time is complex in both direction and dimensionality. Notions like the 'continuous present' (Schudson 1986), 'double time' (Zelizer 1993), journalistic short-sightedness (Patterson 1998) or 'accumulated contemporaneity' (Bodker 2016) underscore time's granular nature, and it is intensified further by the technological environments shaping newswork. Franciscato (2005) notes that the technologies most directly associated with hastening newsmaking have always brought 
to the fore other aspects of temporality: the novelty of newsbooks (Woolf 2001), simultaneity of newspapers (Anderson 1991), periodicity of dailies (Raymond 1996) or instantaneity of telephones (Fedler 2000), among others. Tenenboim-Weinblatt and Neiger $(2017,39-40)$ hold that the 'representation of various layers of past, present and future in news narratives is facilitated and constrained by the temporal features of news technologies and of journalists' work conditions'. The ensuing temporal affordances, they argue, extend across the spectrum of journalistic work, involving immediacy, liveness, preparation time, transience, fixation in time and extended retrievability. Journalists thus regularly use backstages to air the relevance and applicability of journalistic norms and adjust them to conditions on the ground: consider, for instance, how physical danger compromises the ability of reporters in conflict zones to address norms of independent reporting. Without backstages, journalists would be hard-pressed to adjust their normative behaviour to action more suited to the realities of reporting.

Although front and backstages work together in journalism, they do not necessarily do so in complementary ways. Coverage of the release of US journalist Danny Fenster from Myanmar in November of 2021, for instance, displays what Tenenboim-Weinblatt (2013a) calls 'elastic newsworthiness', when a news story's longitudinal visibility intersects with other factors like its political and cultural resonance. Although little detail was known of Fenster's captivity, his release was celebrated on journalism's frontstage as an emotional and joyous reconnection with family members, fitting the story into an already existent mnemonic frame. Journalists skipped over the multiple background questions about the negotiations that had made Fenster's release possible, and little mention was made of the broader punitive landscape for journalists in Myanmar. CNN's Ivan Watson, one of the first few reporters to contextualise the release at the time of its occurrence, pointed to

at least 40 journalists currently behind bars as well as at least eight news organizations that have been shut down completely. Many others have been forced to suspend their operations, all part of a much broader crackdown that has been taking place since the military swept a civilian government from power. (Watson 2021)

Whichever pattern of longitudinal visibility the story takes over the coming months will help determine the ensuing relationship between front and backstage behaviour on this particular story.

Thus, it is no surprise that an array of impulses characterises temporality in newsmaking, underscoring its complexity. The journalistic community and its journalists exist in what might be called an ontological 'time crunch', a circumstance that demands an outward accommodation of normative claims via temporal objectives associated with speed while simultaneously embracing internal impulses that complicate and even undermine the frenzied pacing of newsmaking. Journalistic claims to speed may thus function rhetorically more than realistically, discarded when journalists enter backstages where more granular, multidimensional and multidirectional temporal engagements can ensue.

What does all of this tell us about the complex time of newsmaking? It suggests that its frontstage - its orientation to speed - opens the door to complex temporality and, by extension, to more complex memory work. Temporal activity, then, may be being systematically utilised to reduce the dissonance between aspired normative conditions and messier conditions on the ground. This raises important questions about what it means to espouse complex temporality as an ontological concern and how this impacts adjacent institutions. 


\section{Why current times require complex temporality}

In typical news cycles, scholars have long believed that the most urgent news demanding the most immediate attention ends up securing the most resources - more central display, more extensive coverage, treatment by multiple modalities and repeated treatment over time. Slower or less urgent events, issues and problems are thought to migrate to the back of the news hole, where they receive less resources in conjunction with their weaker claims to immediacy.

And yet, the circumstances of the 2020s all defy slow news treatment. The decade began with multiple news strands of such critical importance and rapid occurrence that their rollout became an endless procession of important but distressing marks on a continuum. The result has been a switch that never turns off, with newsmaking continuously overrun by demands for immediate coverage that exceed its capacity to respond. Speed, then, has become meaningless because it is everywhere.

This directly impacts the temporal activity of both the journalistic community and its journalists. The publication of the Facebook Papers in 2021 offers a useful example: Although the normative nod to speed would have us expect a diminished time frame for forming and processing news judgement, speed was not in play here. The papers' simultaneous publication across scores of news outlets, consensually delayed and kept under wrap by hundreds of journalists until publication, neutralised an investment in speed in lieu of other temporal impulses - simultaneity, collaboration, confirmation, tempo, timing, duration, repetition, anticipation and continuity, among others. It likewise oriented to temporal affordances other than immediacy, such as the time needed to prepare the story or the transience involved in updating it. Importantly, the act of collaborative publishing was itself drawn from the past, following the precedent of the Paradise Papers in 2017 and the Panama Papers five years earlier. Repudiating speed in this instance thereby gave way to a more generative incorporation of time and memory. The act of recognising the limits of temporality's frontstage in effect ushered in its backstage, where, as I've described, memory flows more freely.

It is thus on backstages that more granular temporal qualities and practices can emerge, a development useful for overtaxed institutions to consider. In her lament over empty linear time, Erll (2020) turns to memory and COVID-19 to underscore how the new rhythms of cyclical repetition created by the pandemic have been experienced as either markers of privilege or reminders of unmet needs. Though synchronicity was evident in visible settings - Italians singing from balconies, New Yorkers cheering medical workers or groups congregating around live coverage - the experience of synchronous time has been uneven. The pandemic, she observes, insists on a "paralyzed and frenzied "now," with little time for future-thinking or attention paid to those outside the narrow emergency-frames of collective (usually national) identity' (863).

Erll's description of COVID-time resonates strongly with broader concerns about the inequities and exclusions of the current moment. It also maps remarkably well onto how journalists and the journalistic community inhabit complex temporality. The paralytic 'now' of which she writes describes the core of journalism's frontstage normative nod to speed. But if that nod can also be seen as an invitation to temporal complexity, then journalism can offer its own experience as a model for other environments struggling with ontological concerns.

Given that temporal impulses shift with orchestrated action like the Facebook Papers, we can expect similar shifts when multiple events, issues and problems make simultaneous urgent demands on journalism. Routine newsgathering - where simultaneity is the rule - bears this out. In August of 2021, for instance, New York Governor Andrew Cuomo resigned because of accusations of sexual harassment at the precise moment 
that the US Senate approved long-debated infrastructure legislation. News outlets used a variety of techniques to signal or downplay the competitive demands on their time, with NBC's Kelly O'Donnell observing that Cuomo had effectively 'stepped on the biggest news for the White House in quite some time'. Why, she wondered, had he chosen 'this particular day and even this hour ... to squash' news of the infrastructure bill (O'Donnell 2021)? Because competitive demands on resources occur repeatedly in newswork, time management often pulls ontology into the picture. As an op-ed writer in The Philadelphia Inquirer noted, the surprising coverage of both events - 'impossible until it isn't' - offered proof that pundits cannot be believed (Gutman 2021).

Two examples from the past two years, both about US journalism but also reflective of much newsmaking elsewhere, illustrate how complex time works. The first concerns racial violence and its impact on US newsrooms. As protests of systemic racism intensified in 2020, multiple US institutions, including news outlets, admitted culpability to racist, discriminatory and exclusionist activity. Although most news outlets lodged their admissions in editorial columns, the Los Angeles Times chose to shape its self-criticism by publishing a multi-part series on its own racist attitudes and practices. It began with a 1981 story about 'inner city marauders' who were 'preying on LA suburbs' under the headline 'An Examination of The Times' Failures on Race, Our Apology and a Path Forward' (Los Angeles Times 2020). Pointing to many examples of its racism over time, the outlet recounted how it had covered communities of colour with pernicious stereotypes, without nuance or context, displaying 'at best a blind spot, at worst an outright hostility, for the city's non-white population'. It segued across its roots in white supremacy, orientation to stories for and about white people, cosying up to the LAPD and lack of diversity in the newsroom. Noting that the 'shadows of the past loom over our institution', it apologised for its 'history of racism' and pledged to do better.

A second example occurred at the end of July 2021, when The Washington Post obtained a copy of an unpublished slide show on COVID-19 from inside the Centers for Disease Control and Prevention. Interpreting the unpublished material, the Post reported that fully vaccinated people could pass on the virus in the same way as unvaccinated individuals (Abutaleb et al 2021). The news was so alarming and so contradicted earlier guidance that it splashed across the media almost instantaneously. But the Post's interpretation of the data was wrong, and physicians, epidemiologists and White House officials were among those who rebuked the report. 'The media's coverage doesn't match the moment', said one Biden official. 'It has been hyperbolic and frankly irresponsible in a way that hardens vaccine hesitancy' (Jones 2021).

What matters in both cases is less the original coverage than the way in which individual journalists and the journalistic community self-corrected after the fact. Although the Los Angeles Times' admission of racism coincided with many other outlets making similar admissions, The Times took a deep dive into its own culpability, acting on input from its reporters to provide a complex mnemonic narrative about how seriously it was taking the indictment of racism. Not surprisingly, the series prompted a slew of laudatory responses, from reporters of colour who had earlier hoped to work at The Times but had been discriminated against to readers who had changed their views to reflect the outlet's evolving position on race. With the COVID story, media critics quickly slammed the interpretive error, noting that 'sloppy news coverage makes a bad situation worse' (Jones 2021), and the outlets that had run the erroneous report self-corrected. CNN reporter Jake Tapper, for instance, tweeted facts and numbers to show how wrong the interpretation had been and how decisive the correction was: 'The vaccines remain the best way to protect yourselves from this virus. Period. Full stop' (Tapper 2021). The corrective was widely applauded, as hundreds of physicians compounded the message's reach by retweeting it across their own networks. 
In both cases, individual journalists, recognising that normative behaviour had produced bad newsmaking, led the way to journalism's adjustment and self-correction. They used journalism's backstages to speak to its frontstages, tweaked its interior to repair its exterior and in so doing fostered both more accountability and public involvement in the story. Such activity underscores the need for more than speed, and it offsets the errors of normative time with the self-repair that complex time makes possible.

\section{Conclusion}

This article has argued that the complex time of journalism can be extrapolated to other institutional settings grappling with similarly competitive calls on their resources. Current circumstances are inserting speed into the demands made of most institutional environments, overtaxing them with pressures that they are ill-equipped to resolve: the courts, the police, education or politics are prime examples. But because speed is integral to journalism's normative sense of self, it models for other institutions how to sidestep speed's relentless presence, by pivoting to backstages that make possible more complex temporal and mnemonic activity.

It is worth noting that backstages involve adjustments to norms that are set in place by real people. Although much of what has been offered here focuses more on what Barnier and Hoskins (2018) call 'memory in the wild', it is worth noting that none of it can unfold without 'memory in the head'. While journalism prides itself on being a collective formation, individuals are the vehicle that adjusts the positionalities instrumental to the optimal functioning of newswork. Without them, there would be little distinction between front and backstages and even less utilisation of complex time as a useful antidote to speed.

We are in a moment of ongoing instability, deep uncertainty and momentous change, and none of that looks as if it will slow down or fade anytime soon. As difficult as current times are to inhabit, they offer a bellwether call to think more broadly about what is missing from how we have long understood memory, mind and media. Current times suggest that we may have underestimated the role that journalism plays in this regard. Not only does it regularly segue between aspired and grounded conditions, but its default condition is fast becoming the default for most, if not all, institutional settings. Journalism can help us understand the compulsion of speed, give us intellectual tools to contemplate its mechanics and draw, and set in place mechanisms that can navigate and even offset the generation of unending demands of simultaneity, immediacy and instantaneity.

Complex time need not - and should not - characterise journalism alone. When urgent competitive demands strain limited institutional resources, as has surely been the case these past two years, we need to be considering the range of temporal impulses that can be marshalled to respond, not only those that are upheld rhetorically. Journalism's complex temporality models an engagement with time and memory for institutions across the board. Looking to its existential reliance on complex temporality makes sense, if for no other reason than the ontological uncertainty surrounding the journalistic community and its journalists is sadly not the only place that ontological uncertainty resides.

Acknowledgements. The author thanks the editors for their generative feedback. She also acknowledges the useful conversations with students enrolled in an Annenberg doctoral seminar on Collective Memory and Journalism in the fall of 2021.

Financial support. No funding was received.

Conflict of interest. I have no competing interests. 


\section{References}

Abutaleb Y, Johnson C and Achenbach J (2021) 'The war has changed': Internal CDC document urges new messaging, warns delta infections likely more severe. The Washington Post, 29 July. Available at https://www. washingtonpost.com/health/2021/07/29/cdc-mask-guidance/ (accessed 12 November 2021).

Adam B (1990) Time and Social Theory. Cambridge, UK: Polity.

Ananny M (2018) Anticipating news: What Trump teaches us about how the networked press can and should imagine. In Boczkowski P and Papacharissi Z (eds), Trump and the Media. Cambridge, MA: MIT Press, 101-109.

Anderson B (1991) Imagined Communities. London and New York: Verso Press.

Bailey I (2021) What are we missing in the Afghanistan story? Nieman Reports, 20 August. Available at https:// niemanreports.org/articles/what-are-we-missing-in-the-afghanistan-story/ (accessed 20 November 2021).

Barnier A and Hoskins A (2018) Is there memory in the head, in the wild? Memory Studies 11(4), 386-390.

Bodker H (2016) The times of news websites. In Franklin B and Eldridge S (eds), The Routledge Companion to Digital Journalism Studies. Abingdon: Routledge, 55-63.

Edel C and Shullman D (2021) In the case of conflict with China, check your Cold War analogies. The Washington Post, 15 November. Available at https://www.washingtonpost.com/outlook/2021/11/15/case-conflict-withchina-check-your-cold-war-analogies/ (accessed 20 November 2021).

Edy J (1999) Journalistic uses of collective memory. Journal of Communication 49(2), 71-85.

Erll A (2020) Afterword: Memory worlds in times of corona. Memory Studies 13(5), 861-874.

Farhi P (2021) How obituaries got a jolt of new life in the internet era. The Washington Post, 17 November. Available at https://www.washingtonpost.com/lifestyle/media/media-advance-celebrity-obituaries/2021/11/ 16/36d9a79a-1596-11ec-b976-f4a43b740aeb_story.html (accessed 18 November 2021).

Fedler F (2000) Lessons from the Past: Journalists' Lives and Work, 1950-1950. Prospect Heights, IL: Waveland Press.

Franciscato C (2005) Journalism and change in the experience of time in Western societies. Brazilian Journalism Research 1(1), 155-175.

Goffman E (1959) The Presentation of Self in Everyday Life. New York: Doubleday.

Gutman A (2021) Cuomo's resignation, infrastructure, and why I no longer believe pundits who predict America's bleak future. The Philadelphia Inquirer, 10 August. Available at https://www.inquirer.com/opinion/commentary/ gov-andrew-cuomo-resignation-bipartisan-infrastracture-bill-20210810.html (accessed 12 November 2021).

Hristova M, Ferrandiz F and Vollmeyer J (2020) Memory worlds: Reframing time and the past. Memory Studies 13(5), 777-791.

Huyssen A (2003) Present Pasts. Palo Alto, CA: Stanford University Press.

Jones T (2021) The media is making missteps in covering COVID. Poynter.org Newsletter, 2 August. Available at https:// www.poynter.org/newsletters/2021/the-media-is-making-missteps-in-covering-covid/ (accessed 12 November 2021).

Keightley E (ed) (2012) Time, Media and Modernity. London: Palgrave MacMillan.

Koselleck R (2004) Futures Past. New York, NY: Columbia University Press.

Lang K and Lang GE (1989) Collective memory and the news. Communication 11, 123-139.

Latour B (2017) Anthropology at the time of the Anthropocene. In Brightman M and Lewis J (eds), The Anthropology of Sustainability. Basingstoke: MacMillan, 35-50.

Los Angeles Times (2020) Editorial: An examination of The Times' failures on race, our apology and a path forward. Los Angeles Times, 27 September. Available at https://www.latimes.com/opinion/story/2020-09-27/losangeles-times-apology-racism (accessed 12 November 2021).

Neiger M and Tenenboim-Weinblatt K (2016) Understanding journalism through a nuanced deconstruction of temporal layers in news narratives. Journal of Communication 66(1), 139-160.

O’Donnell K (2021) NBC News Special Report, 12.30 pm, 10 August.

Olick J (2014) Reflections on the undeveloped relations between journalism and memory studies. In Zelizer B and Tenenboim-Weinblatt K (eds), Journalism and Collective Memory. London: Palgrave MacMillan, pp. 17-31.

Patterson T (1998) Time and news: The media's limitations as an instrument of democracy. International Political Science Review 19(1), 55-67.

Pope K (2021) The media's belated rush to judgment on the Trump dossier. Columbia Journalism Review, 17 November. Available at https://www.cjr.org/opinion/the-medias-belated-rush-to-judgment-on-the-trumpdossier.php (accessed 18 November 2021).

Raymond J (1996) The Invention of the Newspaper - English Notebooks, 1641-1649. Oxford: Clarendon Press.

Reich Z and Godler Y (2014) A time of uncertainty: The effect of reporters' time schedule on their work. Journalism Studies 15(5), 607-618.

Ryfe D (2019) The ontology of journalism. Journalism 20(1), 206-209. 
Schudson M (1986) When: Deadlines, datelines and history. In Manoff R and Schudson M (eds), Reading the News. New York: Pantheon Books, 79-108.

Sheller M (2015) News now. Journalism Studies 16(1), 12-26.

Tapper J (2021). Retweet, 1 August. Available at https://twitter.com/AndrewJBates46/status/1421835275911716875 (accessed 12 November 2021).

Tenenboim-Weinblatt K (2013a) The management of visibility: Media coverage of kidnapping and captivity cases around the world. Media, Culture and Society 35(7), 791-808.

Tenenboim-Weinblatt K (2013b) Bridging collective memories and public agendas: Toward a theory of mediated prospective memory. Communication Theory 23(2), 91-111.

Tenenboim-Weinblatt K and Neiger M (2017) Temporal affordances in the news. Journalism 19(1), 37-55.

Usher N (2018) Breaking news production processes in US metropolitan newspapers: Immediacy and journalistic authority. Journalism 19(1), 21-36.

Watson I (2021) CNN, 15 November. Available at https://www.cnn.com/videos/media/2021/11/15/danny-fenster-released-myanmar.cnnbusiness (accessed 18 November 2021).

Wemple E (2020) The media and the Steele Dossier. The Washington Post, 18 April. Available at https://www. washingtonpost.com/opinions/media-steele-dossier/ (accessed 20 November 2021).

Woolf D (2001) News, history and the construction of the present in early modern England. In Dooley B and Baron S (eds), The Politics of Information in Early Modern Europe. London and New York: Routledge, pp. 80-118.

Zelizer B (1993) Journalists as interpretive communities. Critical Studies in Mass Communication 65(5), $219-237$.

Zelizer B (2018) Epilogue: Timing the study of news temporality. Journalism 19(1), 111-121.

Zelizer B (2021) Why journalism's default neglect of temporality is a problem. Media, Culture \& Society. Available at https://doi.org/10.1177\%2F01634437211015846 (accessed 10 November 2021).

Zerubavel E (2005) Time Maps. Chicago: University of Chicago Press.

Barbie Zelizer is the Raymond Williams Professor of Communication and Director of the Center for Media at Risk at the University of Pennsylvania's Annenberg School for Communication. A former journalist, Zelizer's work focuses on journalism, culture, memory and images. Her most recent co-authored book is The Journalism Manifesto (Polity, 2021).

Cite this article: Zelizer B (2022). What journalism tells us about memory, mind and media. Memory, Mind \& Media 1, e6, 1-11. https://doi.org/10.1017/mem.2021.9 